\title{
Evaluation of Nurses' Knowledge Levels on Evidence-based Acute Stroke
}

\author{
Hemşirelerde Kanıta Dayalı Akut İnme Bilgi Düzeyinin Değerlendirilmesi
}

\author{
${ }^{1}$ Karadeniz Technical University Faculty of Health Sciences, Department of Nursing, Department of Public Health Nursing, Trabzon, Turkey \\ 2Karadeniz Technical University Health Sciences Institute, Department of Internal Medicine Nursing, Trabzon, Turkey
}

\begin{abstract}
Objective: This study aimed to evaluate the evidence-based acute stroke knowledge level in nurses.

Materials and Methods: This descriptive study consisted of 245 nurses who work in Farabi Hospital of Karadeniz Technical University Health Application and Research Center in Trabzon city center. Data are collected using "Introductory Information Form" and "Acute Stroke Knowledge Level Measurement and Awareness Form" created within the scope of "T.R. Ministry of Health Stroke Clinical Protocol". The suitability of data for normal distribution was evaluated with the Shapiro-Wilk and Kolmogorov-Smirnov tests. One-Way analysis of variance and independent samples t-test to were used to compare the data with normal distribution, whereas the Kruskal-Wallis and Mann-Whitney U test to compare data without normal distribution and chi-square test for categorical data. The significance level was taken as p values of $<0.05$.

Results: The average age of the nurses was $32.19 \pm 7.76$ (minimum: 20, maximum: 60) years, wherein 64.9\% had a bachelor's degree and $93.1 \%$ were clinical/ service nurses. The common correct answers were given to questions about nursing care in acute stroke, whereas wrong answers to questions about stroke scale, tPA dose, and stroke time management. A positive, weak, and statistically significant relationship was found between the knowledge score of the nurses and their ages $(r=0.158 ; p=0.013)$. Nurses who followed professional publications and attended congresses, courses, and symposium programs answered the questions more accurately.

Conclusion: Improving the knowledge level of nurses on acute stroke is necessary to organize postgraduate and in-service training programs to ensure the participation of nurses in scientific meetings and develop stroke care clinical practice guidelines for quality patient care.
\end{abstract}

Keywords: Stroke, acute stroke, nurse, evidence-based nursing

\section{$\ddot{O} z$}

Amaç: Bu çalışma hemşirelerde kanıta dayalı akut inme bilgi düzeyinin değerlendirilmesi amacıyla yapılmıştır.

Gereç ve Yöntem: Tanımlayıcı tipteki bu çalışmanın örneklemini Trabzon il merkezinde yer alan Karadeniz Teknik Üniversitesi Sağlık Uygulama Araştırma Merkezi Farabi Hastanesi’nde çalışan 245 hemşire oluşturmuştur. Veriler “Tanıtıcı Bilgi Formu” ve "T.C. Sağlık Bakanlığı İnme Klinik Protokolü” kapsamında oluşturulan “Akut İnme Bilgi Düzeyi Ölçme ve Farkındalık Formu” kullanılarak toplanmıştır. Verilerin normal dă̆glıma uygunluğu Shapiro-Wilk ve KolmogorovSmirnov testleri ile değerlendirilmiştir. Normal dağılımı olan verilerin karşılaştırılmasında tek yönlü varyans analizi ve bağımsız örnekler t-testi, normal dağılım göstermeyenlerde Kruskal-Wallis ve Mann-Whitney U testi, kategorik olan verilerde ki-kare testi kullanılmıştır. Bu çalışmada önem düzeyi p<0,05 alınmıştır.

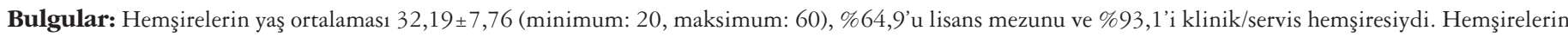
en fazla doğru yanıtladığ yönetimiydi. Hemşirelerin bilgi puanı ile yaş arasında pozitif yönlü zayıf, istatistiksel olarak anlamlı ilişki bulundu $(r=0,158 ; \mathrm{p}=0,013)$. Mesleki yayınları takip eden, kongre, kurs ve sempozyum programlarına katılan hemşireler soruları daha yüksek oranda doğru yanıtladı.

Sonuç: Hemşirelerin akut inme bilgi düzeyinin artırılması ve nitelikli hasta bakımı yönetimi için mezuniyet sonrası ve hizmet içi eğitim programları düzenlenmeli, bilimsel toplantılara katılım sağlanmalı ve inme bakımı klinik uygulama kılavuzları geliştirilmelidir.

Anahtar Kelimeler: İnme, akut inme, hemşire, kanıta dayalı hemşirelik

Address for Correspondence/Yazışma Adresi: Havva Karadeniz PhD, Karadeniz Technical University Faculty of Health Sciences, Department of Nursing, Department of Public Health Nursing, Trabzon, Turkey

Phone: +90 4622300476 E-mail: hkmumcu@yahoo.com ORCID: orcid.org/0000-0001-7482-7789

Received/Geliss Tarihi: 10.09.2021 Accepted/Kabul Tarihi: 03.12.2021

${ }^{\circ}$ Copyright 2021 by Turkish Neurological Society

Turkish Journal of Neurology published by Galenos Publishing House. 


\section{Introduction}

Accompanied by focal loss of cerebral function, stroke is defined as a rapidly progressing clinical condition that occurs as a result of the neurons' inability to access glucose, oxygen, and other chemicals that are needed to maintain their vitality due to vascular reasons (1). In 2020, 61 million people were estimated to die from stroke (2).

Nurses are of vital importance in the accurate and timely detection of stroke symptoms, reduction of morbidity and mortality of in-hospital strokes, and appropriate and efficient use of resources. Nurses tend to be the first healthcare professionals to identify stroke symptoms in inpatients (3). Post-stroke nursing interventions include preventing secondary brain injury, protecting the airways, general body support, and preventing complications (4).

Nurses should use evidence-based care practices to achieve a positive clinical outcome in patients with stroke (4). Evidencebased practices are defined as "integrating individual clinical expertise with the best external clinical evidence available from systematic research in addition to the conscious, explicit, and reasonable use of the best available evidence when making patientspecific decisions on patient care" (5). Factors, such as increased care costs, inconsistent health care, ongoing and traditional care approaches, decreased trust in healthcare personnel observed in individuals who will receive treatment and care, anxiety for wrong practices, and increased information requests, have led to an increased evidence-based practice approaches (6). For more than two decades, evidence-based stroke care has been found to save lives, reduce disability, and shorten hospital stay, and is often associated with improved patient outcomes. Evidence-based care practices are critical in providing optimum patient outcomes and high-quality interdisciplinary care not only in the acute phase but also in the rehabilitation phase of stroke (4).

Nurses should be aware of new evidence-based advances to provide quality patient care. Nurses who care or have the potential to care for patients with stroke should use evidence of stroke. The Turkish Ministry of Health published the Stroke Clinical Protocol in 2017. Further scientific studies that are conducted in this field will highlight nursing interventions in acute stroke and analyze nursing roles and inputs in pre-hospital, emergency service, and transfer stages, with necessary updates, taking into account the evidence-based recommended approaches so far.

\section{Materials and Methods}

This descriptive study was conducted in a university hospital to evaluate the evidence-based acute stroke knowledge level of nurses. The population consisted of 496 nurses. Operating room nurses (58) were excluded from the study since they have a short duration in patients' care and follow-up. The study was conducted with 245 volunteer nurses without sampling. The data were collected using the descriptive information form and the acute stroke knowledge level assessment and awareness form.

\section{The Descriptive Information Form}

Developed using the literature and the Turkish Neurological Society's Stroke Clinical Protocol Impact Assessment scale, the form includes a total of 16 questions regarding the sociodemographic characteristics of nurses (age, gender, educational status, professional experience, and position), professional development (following scientific publications and participation in scientific meetings), and their knowledge levels of the Ministry of Health Stroke Clinical Protocol.

The Acute Stroke Knowledge Level Assessment and Awareness Form

This form was created by reviewing the T.R. Ministry of Health Stroke Clinical Protocol 2017, wherein the information and care categories that should be considered in the acute period include early diagnosis, time management, imaging and laboratory studies, supportive therapy, vital signs and neurological follow-up, activity, nutrition, and dysphagia screening. These care categories are considered as factors that worsen the prognosis when evaluated incorrectly and interventions are inappropriately performed.

\section{Data Collection}

The nurses filled in the descriptive introductory information form and the acute stroke knowledge level assessment and awareness form during working hours through the face-to-face interview method.

\section{Limitations of the Study}

The most important limitation of the study is that after excluding 58 nurses working in the operating room, 245 (55.9\%) out of 496 nurses who agreed to participate in the study were included in the sample. Additionally, the study was conducted with nurses who voluntarily participated in the study in a certain period only in one hospital, thus results can only be generalized to its population.

\section{Ethical Considerations}

Ethical permission from Karadeniz Technical University Faculty of Medicine Clinical Research Ethics Committee (protocol number: 219/228, number: 24237859-569), permission from the relevant institution, and informed consent from the nurses who participated in the study were obtained before the study.

\section{Statistical Analysis}

The compliance of the data with a normal distribution was examined using the Shapiro-Wilk test and Kolmogorov-Smirnov test. The data with normal distribution were presented as mean $( \pm)$ and standard deviation, non-normally distributed data were presented as median (minimum and maximum), and qualitative data as frequency. The Spearman rank correlation and chi-square test were used to analyze the data. The significance level was considered as $\mathrm{p}$ values of $<0.05$.

\section{Results}

The results showed that $86.5 \%$ of nurses were female, with an average age of $32.19 \pm 7.76$ (minimum: 20, maximum: 60) years, wherein $64.9 \%$ had bachelor's degrees, and $93.1 \%$ were service nurses.

Of the nurses, $17.6 \%$ followed professional publications, $4.5 \%$ attended a neurology-related course/certificate program, $25.7 \%$ followed evidence-based guidebook/research/literature in the last 
6 months, $63.3 \%$ attended congresses/symposiums/courses, and $16.3 \%$ were aware of the stroke protocol (Table 1 ).

Of the nurses, $21.2 \%$ knew about the stroke center/patient bed and $87.3 \%$ correctly answered the ischemic stroke triage questions. Additionally, $48.2 \%, 23 \%$, and $36.3 \%$ of nurses knew that computerized brain tomography (CBT) should be completed and interpreted within $45 \mathrm{~min}$ following the emergency application, treatment with intravenous tissue plasminogen activator (IV tPA) should begin at the onset of the $4.5 \mathrm{~h}$ stroke symptom, and the recommended dose of IV tPA for stroke patients should be $0.9 \mathrm{mg} /$ $\mathrm{kg}$, respectively. Of the nurses, $64.1 \%$ knew that the recommended time for IV tPA application in ischemic stroke should be $60 \mathrm{~min}$ between the entry to the emergency room and treatment and $69.8 \%$ knew that the neurological status and vital signs of a patient with ischemic stroke should be frequently evaluated up to $24 \mathrm{~h}$ after the administration of IV tPA. Additionally, $33.9 \%$ and $28.2 \%$ of nurses correctly replied to the questions about the follow-up of vital signs in patients who underwent recanalization treatment and post-treatment neurological follow-up, respectively.

Of the nurses, 93.1\% did not know that $24 \mathrm{~h}$ CBT should be performed in patients undergoing IV tPA, whereas $86.9 \%$ of the nurses did not know that coagulation parameters should be studied alone in hospitalization. Additionally, $86.9 \%$ were aware that coagulation parameters should be analyzed only during hospitalization.

Nurses knew that dysphagia screening should be performed within $24 \mathrm{~h}$ after hospitalization (92.7\%), should be aimed to reach daily calorie and protein intake within $72 \mathrm{~h}(87.8 \%)$, blood pressure value should be reduced below $185 / 110 \mathrm{mmHg}$ before IV tPA is given $(93.1 \%)$, patients should be mobilized within the first $24 \mathrm{~h}(76.7 \%)$, and high fever, seizure activity, and hyperglycemia worsen the prognosis of stroke (96.7\%) (Table 2).

According to the educational status of the nurses, no significant difference was found in acute stroke knowledge level variables (p>0.050) (Table 3).
The Spearman rank correlation analysis revealed a positively weak statistically significant relationship between knowledge score and age $(\mathrm{r}=0.158 ; \mathrm{p}=0.013)$. However, no statistically significant relationship was seen between the years of work experience knowledge score $(r=0.064 ; \mathrm{p}=0.334)$ (Table 4).

The most commonly correctly answered question is the nursing care in acute stroke, whereas the least commonly correctly answered were about the stroke scale, tPA dose, and stroke time management. The most common correctly answered questions are as follows: "High fever, seizure activity, and hyperglycemia worsen the prognosis of stroke". (Question 34, 96.7\%); "BT should be done in the $24^{\text {th }}$ hour after treatment in patients undergoing recanalization”. (Question 28, 93.1\%); "Before IV tPA is given for ischemic stroke, what level should the blood pressure be lowered to." (Question 32, 93.1\%); "All patients with stroke should be screened for dysphagia within the first $24 \mathrm{~h}$ after hospitalization for oral intake reliability". (Question 30, 92.7\%); "All patients should be evaluated in terms of malnutrition risk within the scope of the nutritional plan, and it should be aimed to reach the target daily calorie and protein intake levels within 72 hours" (Question $31,87.8 \%$ ) (Figure 1).

The least common correctly answered questions were as follows: "Which stroke scale is preferably used in the neurological examination?" (Question 20, 11.8\%); "How long after the onset of stroke symptoms should IV tPA be initiated?" (Question 22, $23.7 \%$ ); "Which of the following is the recommended IV tPA dose for patients with ischemic stroke?" (Question 23, 36.3\%); "To clarify the diagnosis of acute ischemic stroke, exclude other differential diagnoses, and evaluate the appropriateness of recanalization therapy, how long after the emergency admission is parenchymal imaging recommended to be completed and interpreted?” (Question 21, 48.2\%) (Figure 2).

Table 1. Nurses' attitudes toward improving their professional knowledge $(n=245)$

\section{Attitudes}

Following professional publications

Yes

No

Sometimes

Attending a certificate/course program related to neurology

Yes

No

Following evidence-based guidelines/research/literature in the last 6 months

Yes

No

Attending congresses/symposiums/courses

Yes

No

Being aware of the stroke protocol

Yes

No n

43

71

131

234

63

182

155

90

40

205
16.3

17.6

29.0

53.5

4.5

95.5

25.7

74.3

63.3

36.7

83.7 


\section{Table 2. Nurses' acute stroke knowledge levels $(n=245)$}

\section{Questions}

Having information about the stroke center/patient bed

Yes

No

Which one is ischemic stroke triage?

A unilateral decrease in arm/leg strength, facial drooping/asymmetry, difficulty in speaking 214

Seizures, dizziness, vomiting

Decreased level of consciousness, decreased strength in left leg/right arm

Disorientation, photophobia, headache

How long does it take before the case can be diagnosed as a possible acute stroke?

6 hours

12 hours

24 hours

48 hours

Which stroke scale is preferably used?

Glasgow Coma scale

*NIHSS

Glasgow Coma scale, *NIHSS

Don't know

In how many minutes should the CBT be completed and interpreted following the emergency application?

25 minutes

35 minutes

45 minutes

60 minutes

How long after the onset of stroke symptoms should IV tPA be initiated?

3 hours

3.5 hours

4 hours

4.5 hours

What is the recommended IV tPA dosage for patients with ischemic stroke?

$0.3 \mathrm{mg} / \mathrm{kg}$

$0.5 \mathrm{mg} / \mathrm{kg}$

$0.7 \mathrm{mg} / \mathrm{kg}$

$0.9 \mathrm{mg} / \mathrm{kg}$

What is the recommended time between emergency room entry and treatment initiation in ischemic stroke?

30 minutes

60 minutes

90 minutes

120 minutes

How long should the patients be frequently evaluated after IV tPA administration in acute stroke?

12 hours

24 hours

36 hours

48 hours
62

n

52

21.2

193

78.8

$214 \quad 87.3$

$14 \quad 5.7$

$12 \quad 4.9$

5

2.0

170

69.4

34

13.9

35

14.3

6

2.4

$\begin{array}{ll}64 & 26.1 \\ 29 & 11.8 \\ 2 & 0.8 \\ 150 & 61.2\end{array}$

25.3

25

10.2

118

48.2

40

16.3

102

41.6

34

13.9

51

20.8

58

23.7

41

16.7

73

29.8

42

17.1

89

36.3

26.1

64.1

5.3

13

4.5

50

20.4

171

69.8

4

1.6

20

8.2 
Table 2. continued

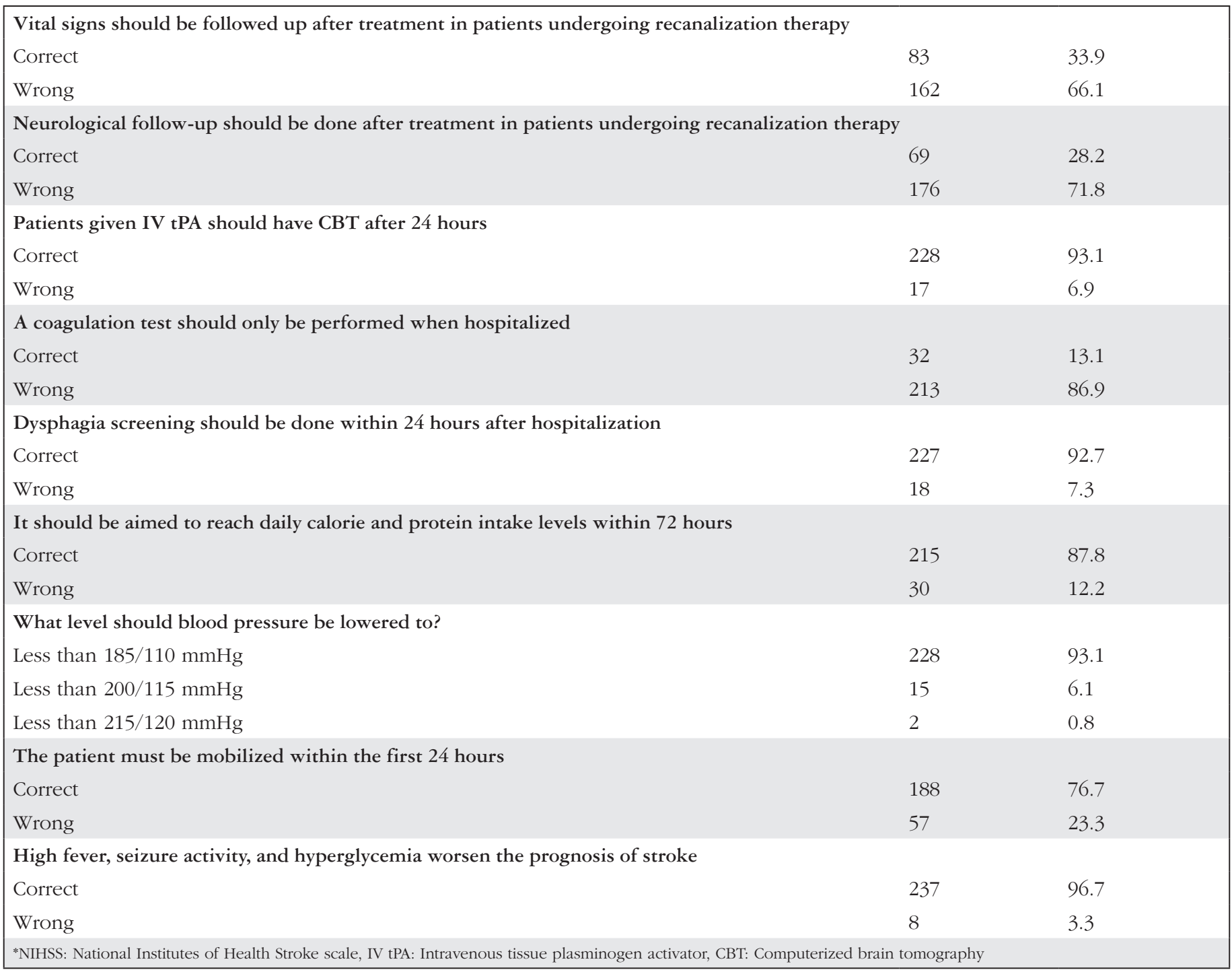

\section{Discussion}

When an evidence-based approach and care is applied to patients with stroke, healthcare professionals will find it easier to make patient-centered decisions and thus create an integrity of patient care. Evidence-based patient-centered approaches are effective in reducing mortality and using resources more efficiently in the treatment process (7). The use of evidence-based information in nursing care practices provides patients with highquality care (8).

This study showed that $25.7 \%$ of the nurses followed evidencebased guidelines/research/literature in the last 6 months (Table 1). The nurses' level of evidence-based acute stroke knowledge did not significantly differ according to their status of following evidence-based guidelines/research/literature in the last 6 months ( $p>0.050)$. A study by Harper (8) evaluated the knowledge about evidence-based ischemic stroke care only in emergency nurses and reported that $45 \%$ of participants followed the literature on evidence-based ischemic stroke care in the last 1 year. Participants who followed the literature on evidence-based ischemic stroke care were found to have a significantly higher mean test score than those who did not (8). The study conducted by Traynelis revealed that $83 \%$ of participants read the literature on ischemic stroke in the last 1 year, but they did not have a significant difference in test scores compared to the participants who did not (9). The result of our research was lower than both studies. Considering this situation, especially within the scope of postgraduate education and in-service training, is appropriate.

Of the nurses, $63.3 \%$ attended the congress/symposium/ course and $4.5 \%$ neurology-related attended the course/certificate program (Table 1). Participation in the course/certificate program revealed a significant difference in the responses given to the question "It should be aimed to reach daily calorie and protein intake within 72 hours" ( $\mathrm{p}<0.001)$ but did not reveal a significant difference with other variables $(\mathrm{p}>0.05)$. 
Table 3. Comparison of the acute stroke knowledge levels of nurses according to their educational status

\begin{tabular}{|c|c|c|c|c|c|}
\hline Questions & $\begin{array}{l}\text { High school } \\
(\mathrm{n}=32)\end{array}$ & $\begin{array}{l}\text { Associate degree } \\
(\mathrm{n}=41)\end{array}$ & $\begin{array}{l}\text { Undergraduate and } \\
\text { postgraduate }(n=172)\end{array}$ & $\begin{array}{l}\text { Test } \\
\text { statistics }\end{array}$ & $\mathrm{p}$ \\
\hline \multicolumn{6}{|c|}{ Which one is ischemic stroke triage? } \\
\hline $\begin{array}{l}\text { A unilateral decrease in } \\
\text { arm/leg strength, facial } \\
\text { drooping/asymmetry, difficulty } \\
\text { in speaking }\end{array}$ & $24(75)$ & $37(90.2)$ & $153(89)$ & \multirow{4}{*}{$\chi 2: 9.563$} & \multirow{4}{*}{0.144} \\
\hline Seizures, dizziness, vomiting & $5(15.6)$ & $1(2.4)$ & $8(4.7)$ & & \\
\hline $\begin{array}{l}\text { Decreased level of } \\
\text { consciousness, decreased } \\
\text { strength in left leg/right arm }\end{array}$ & $3(9.4)$ & $2(4.9)$ & $7(4.1)$ & & \\
\hline $\begin{array}{l}\text { Disorientation, photophobia, } \\
\text { headache }\end{array}$ & $0(0)$ & $1(2.4)$ & $4(2.3)$ & & \\
\hline \multicolumn{6}{|c|}{ How long does it take before the case can be diagnosed as a possible acute stroke? } \\
\hline 6 hours & $19(59.4)$ & $33(80.5)$ & $118(68.6)$ & \multirow{4}{*}{$\chi 2: 9.157$} & \multirow{4}{*}{0.165} \\
\hline 12 hours & $3(9.4)$ & $3(7.3)$ & $28(16.3)$ & & \\
\hline 24 hours & $8(25)$ & $4(9.8)$ & $23(13.4)$ & & \\
\hline 48 hours & $2(6.3)$ & $1(2.4)$ & $3(1.7)$ & & \\
\hline \multicolumn{6}{|c|}{ Which stroke scale is preferably used? } \\
\hline NIHSS & $3(9.4)$ & $6(14.6)$ & $20(11.6)$ & \multirow{4}{*}{$\chi 2: 3.181$} & \multirow{4}{*}{0.786} \\
\hline Glasgow Coma scale & 7 (21.9) & $8(19.5)$ & $49(28.5)$ & & \\
\hline Glasgow Coma scale/NIHSS & $0(0)$ & $0(0)$ & $2(1.2)$ & & \\
\hline Don't know & $22(68.8)$ & $27(65.9)$ & $101(58.7)$ & & \\
\hline \multicolumn{6}{|c|}{ What is the recommended time between emergency room entry and treatment initiation in ischemic stroke? } \\
\hline 30 minutes & $8(25)$ & $9(22)$ & $47(27.3)$ & \multirow{4}{*}{$\chi 2: 3.856$} & \multirow{4}{*}{0.696} \\
\hline 60 minutes & $21(65.6)$ & $30(73.2)$ & $106(61.6)$ & & \\
\hline 90 minutes & $2(6.3)$ & $0(0)$ & $11(6.4)$ & & \\
\hline 120 minutes & $1(3.1)$ & $2(4.9)$ & $8(4.7)$ & & \\
\hline \multicolumn{6}{|c|}{ How long should the patient be frequently evaluated after the administration of IV tPA in acute stroke? } \\
\hline 12 hours & $8(25)$ & $14(34.1)$ & $28(16.3)$ & \multirow{4}{*}{$\chi 2: 10.735$} & \multirow{4}{*}{0.097} \\
\hline 24 hours & $21(65.6)$ & $26(63.4)$ & $124(72.1)$ & & \\
\hline 36 hours & $0(0)$ & $1(2.4)$ & $3(1.7)$ & & \\
\hline 48 hours & $3(9.4)$ & $0(0)$ & $17(9.9)$ & & \\
\hline \multicolumn{6}{|c|}{ Vital signs should be followed up after treatment in patients undergoing recanalization therapy } \\
\hline Correct & $7(21.9)$ & $12(29.3)$ & $64(37.2)$ & \multirow{2}{*}{$\chi 2: 3.299$} & \multirow{2}{*}{0.192} \\
\hline Wrong & $25(78.1)$ & $29(70.7)$ & $108(62.8)$ & & \\
\hline \multicolumn{6}{|c|}{ Neurological follow-up should be done after treatment in patients undergoing recanalization therapy } \\
\hline Correct & $30(93.8)$ & $39(95.1)$ & $159(92.4)$ & \multirow{2}{*}{$\chi 2: 0.395$} & \multirow{2}{*}{0.821} \\
\hline Wrong & $2(6.3)$ & $2(4.9)$ & $13(7.6)$ & & \\
\hline \multicolumn{6}{|c|}{ Dysphagia screening should be done within 24 hours after hospitalization } \\
\hline Correct & $28(87.5)$ & $39(95.1)$ & $160(93)$ & \multirow{2}{*}{$\chi 2: 1.650$} & \multirow{2}{*}{0.438} \\
\hline Wrong & $4(12.5)$ & $2(4.9)$ & $12(7)$ & & \\
\hline \multicolumn{6}{|c|}{ It should be aimed to reach daily calorie and protein intake levels within 72 hours } \\
\hline Correct & $29(90.6)$ & $36(87.8)$ & $150(87.2)$ & \multirow{2}{*}{$\chi 2: 0.293$} & \multirow{2}{*}{0.864} \\
\hline Wrong & $3(9.4)$ & $5(12.2)$ & $22(12.8)$ & & \\
\hline
\end{tabular}


Table 3. continued

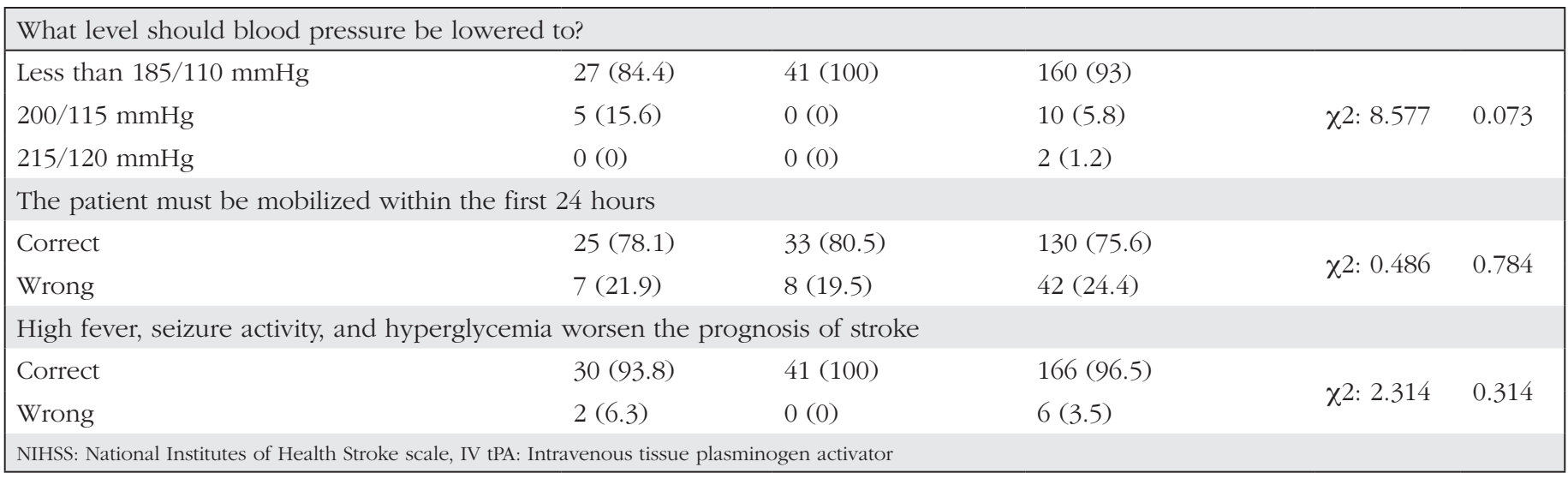

Table 4. Relationship between the nurses' age, years of work experience, and knowledge score

\begin{tabular}{|c|c|c|c|c|c|}
\hline Features & Mean & Standard deviation & Median & Minimum & Maximum \\
\hline Age & 32.2 & 7.8 & 30 & 20 & 60 \\
\hline Years of work experience (month) & & Knowledge score & & & \\
\hline Features & & $\mathbf{r}$ & & $\mathrm{p}$ & \\
\hline r: Spearman rank correlation & & & & & \\
\hline
\end{tabular}



Figure 1. The most common correct answers

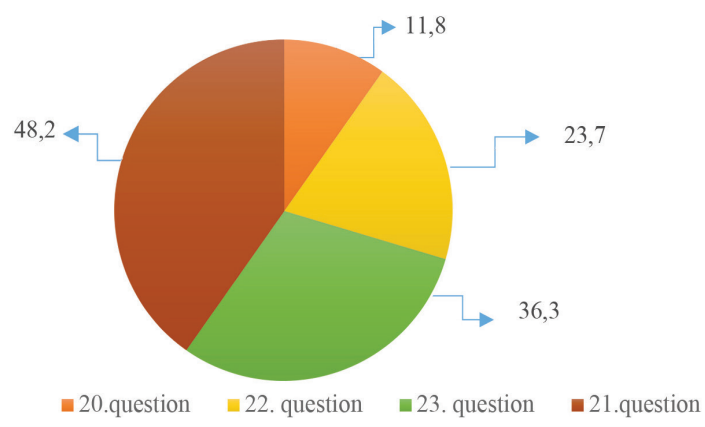

Figure 2. The least common correct answers
The study by Traynelis with 63 participants, which is an extension of Harper's study, revealed that those participating in the continuous education program on stroke got significantly higher scores than those who did not $(\mathrm{p}<0.02)(9)$.

The nurses were asked how often vital signs and neurological follow-up were done after IV tPA application in acute stroke, and $33.9 \%$ answered the questions about vital signs follow-up correctly, whereas $28.2 \%$ in neurological follow-up and $69.8 \%$ in "How long should the patient be frequently evaluated after the administration of IV tPA in acute stroke?" (Table 2). Our study assumed that patients who received IV tPA were monitored, thus approaches without electronic equipment support such as manual pulse count, were not questioned.

Nurses were asked about the door-to-needle time in acute stroke and the ratio of those who correctly answered the doorto-needle time as 60 min was $64.1 \%$ in our study. Additionally, $48.2 \%$ of the nurses correctly answered the question on the duration after the emergency application for the CBT completion and interpretation as 45 minutes (Table 2). The study of Fant and Lakomy (10) investigated the timing of nursing care for patients with hyperacute stroke on registered nurses with a certificate on stroke and concluded a significant difference between the nurses who are certified in meeting the time targets specified in the clinical protocol and those who were not. The compliance of the certified nurses to the timing was found to be the same as the protocol. Those without certificates could not attain their goals for the timing from the door-to-teleneurology and the door-toalteplase application (10). 
Almost all nurses $(96.7 \%)$ correctly answered the question "High fever, seizure activity, and hyperglycemia worsen the prognosis of stroke" (Table 2). The results of these two studies are quite different since studies were conducted in different countries and with different groups of nurses.

Of the nurses, $36.3 \%$ correctly knew that the recommended IV tPA dose for patients with ischemic stroke should be $0.9 \mathrm{mg} /$ $\mathrm{kg}$ (Table 2). A study involving 226 nurses (mean age 31.27, $81.9 \%$ with a diploma, $11.1 \%$ undergraduate degree, and $7.1 \%$ postgraduate degree) that examined the factors affecting the nurses' stroke knowledge and their performance in stroke used The Stroke Information Evaluation scale developed by Thomas et al. (11). Wherein, $44.2 \%$ of the nurses stated that the IV tPA dose should be $0.9 \mathrm{mg} / \mathrm{kg}$ (11). Our study revealed a lower ratio of correct answers. This result might be related to the low level of awareness of the nurses about the SB Stroke Clinical Protocol.

Of the nurses, $87.3 \%, 69.4 \%$, and $64.1 \%$ correctly answered the questions "Which one is ischemic stroke triage?"; "How long does it take before the case can be diagnosed as a possible acute stroke?"; and "What is the recommended time between emergency room entry and treatment initiation in ischemic stroke?", respectively (Table 2). Khatab et al. (12) noted in their study with 80 nurses that $63.7 \%$ of nurses did not have enough information about cerebral stroke and nursing management in the first golden hours of a stroke since they do not participate in a continuous educational program. The same study revealed no statistically significant relationship between the practice behaviors of nurses during the golden hours of stroke and their demographic characteristics (12). Similarly, our study revealed an insufficient nurses' knowledge about acute stroke, which may also have resulted from the lack of ongoing education after graduation and not participating in scientific programs related to the subject.

No significant difference was found in the variables related to acute stroke knowledge level according to the educational status of the nurses $(\mathrm{p}>0.050)$ (Table 3$)$. The preferred stroke scales varied according to the titles of the nurses $(\mathrm{p}=0.014)$. The study conducted by Mohammed (13) revealed a statistically significant relationship between evidence-based nursing practice knowledge levels and age, educational status, and job title. Another study revealed no statistically significant relationship between the nurses' general knowledge of evidence-based nursing practices and their years of work experience or their participation in the training program/workshop (13).

This study revealed no statistically significant relationship between the years of work experience of nurses and their knowledge score $(r=0.064 ; p=0.334)$ (Table 4). Adelman et al. (14) evaluated the emergency and inpatient nurses, of whom most have $>10$ years of clinical experience, to describe three major stroke symptoms. Of the nurses, $>85 \%$ were found to have sufficient knowledge about the signs and symptoms of a stroke (14). The research conducted by Harper (8) highlighted higher test scores of participants who had more years of experience in emergency nursing. A study in which 50 nurses with >2 years of experience in Mansoura University Hospital were included, determined that $84 \%$ of the nurses had insufficient knowledge about evidence-based nursing practices (13). The result of our research is lower than the other two studies since nurses had more stroke cases due to their long years of working in emergency services in the other studies.
Our study revealed a positive weak statistically significant correlation between the median value of correct response and age $(\mathrm{r}=0.158 ; \mathrm{p}=0.013)$ (Table 4$)$. The research conducted by $\mathrm{Ab}$ Malik et al. (15) revealed that the high average age was associated with high performance. The results of these two studies are similar to our research, which may have resulted from the experience gained during the working years.

\section{Study Limitations}

The generalizability of the findings of this study was limited; however, it was observed that insufficient evidence-based acute stroke information in nurses was quite high. Only one-fifth of the nurses were able to correctly answer the information and practices essential in nursing care in acute stroke. Nurses who followed professional publications and participated in congresses, symposiums, and course programs answered the acute stroke knowledge level questions more accurately. A positive, weak, statistically significant relationship was found between the knowledge score of the nurses and age, but without a statistically significant correlation between the years of work experience and knowledge scores.

\section{Conclusion}

Our study results can be used to improve and make training programs on stroke widespread to increase the knowledge level of nurses and shared with hospital management, executive nurses, and nurses to promote the clinical performance of nurses. Postgraduate training and in-service training programs can be organized for the management of patient care in acute stroke. Stroke care clinical practice guidelines can be created for patients with acute stroke and more comprehensive studies can be conducted to develop a care guideline. Nurses can be guided to attend congresses, courses, and symposiums to improve their knowledge level. The National guidelines for acute stroke care can be included in the curriculum in nursing schools, and further studies with wider participation of nurses can be planned to determine the necessary information about acute stroke.

\section{Ethics}

Ethics Committee Approval: Ethical permission from Karadeniz Technical University Faculty of Medicine Clinical Research Ethics Committee (protocol number: 219/228, number: 24237859-569).

Informed Consent: Informed consent from the nurses who participated in the study were obtained before the study.

Peer-review: Externally and internally peer-reviewed.

\section{Authorship Contributions}

Concept: H.K., N.M.Y., Design: H.K., N.M.Y., Data Collection or Processing: H.K., N.M.Y., Analysis or Interpretation: H.K., N.M.Y., Literature Search: N.M.Y., W riting: H.K., N.M.Y.

Conflict of Interest: No conflict of interest was declared by the authors.

Financial Disclosure: The authors declared that this study received no financial support. 


\section{References}

1. Woodward S, Mestecky A. The Journal of Neuroscience Nursing: Evidence based practices. Translated by: Topçuoğlu MA, Durna Z, Karadakovan A. Nobel Medical Bookstores Limited Company: İstanbul 2013:357-375.

2. World Health Organization (2015). Global burden of stroke [through internet]. resource: http://www.who.int/cardiovascular_diseases/en/cvd_ atlas_15_burden_stroke.pdf?ua=. [Access 6 December 2019]

3. George P, Wisco DR, Gebel J, Uchino K, Newey CR. Nurses Are as Specific and Are Earlier in Calling In-Hospital Stroke Alerts Compared to Physicians. J Stroke Cerebrovasc Dis 2017;26:917-921.

4. Theofanidis D, Gibbon B. Nursing interventions in stroke care delivery: An evidence-based clinical review. J Vasc Nurs 2016;34:144-151.

5. Baatiema L, Otim M, Mnatzaganian G, et al. Towards best practice in acute stroke care in Ghana: a survey of hospital services. BMC Health Serv Res 2017; 17:108.

6. Yurtsever S, Altıok M. Evidence-based practices and nursing. Firat University Journal of Health Sciences 2006;20:159-166.

7. Durna Z, Akyil RÇ. Multidisciplinary rehabilitation in individuals with stroke. Turkey Clinics Journal of Internal Medicine Nursing-Special Topics 2015;1:72-82.

8. Harper JP. Emergency nurses' knowledge of evidence-based ischemic stroke care: a pilot study. J Emerg Nurs 2007;33:202-207.
9. Traynelis L. Emergency department nurses' knowledge of evidence-based ischemic stroke care. Kaleidoscope 2012;10:1-8.

10. Fant GN, Lakomy JM. Timeliness of Nursing Care Delivered by Stroke Certified Registered Nurses as Compared to Non-Stroke Certified Registered Nurses to Hyperacute Stroke Patients. J Neurosci Nurs 2019;51:54-59.

11. Thomas L, Harrington K, Rogers H, et al. Development of a scale to assess nurses' knowledge of stroke: a pilot study. Clin Rehabil 1999;13:518-526.

12. Khatab R, Gomaa N, Saaed A. Factors affecting nursing performance in caring patients with cerebral stroke during first golden hours. EvidenceBased Nursing Research 2019;1:55-64.

13. Mohammed SR. Assessment of emergency nurses' knowledge about evidence based nursing practice for ischemic stroke patients. Mansoura Nursing Journal 2015;2:18-30.

14. Adelman EE, Meurer WJ, Nance DK, et al. Stroke awareness among inpatient nursing staff at an academic medical center. Stroke 2014;45:271273.

15. Ab Malik N, Mohamad Yatim S, Lam OLT, Jin L, McGrath C. Factors influencing the provision of oral hygiene care following stroke: an application of the Theory of Planned Behaviour. Disabil Rehabil 2018;40:889-893. 